\title{
Laboratory diagnosis of megaloblastic anaemia: current methods assessed by external quality assurance
} trials

\author{
D W DAWSON,* D I FISH,* I D O FREW $\dagger$, T ROOME†, I TILSTON $\dagger$ \\ From the Department of *Haematology, North Manchester General Hospital, Manchester, and †Good Hope \\ Hospital, Sutton Coldfield, West Midlands
}

SUMMARY The results of an Interregional quality assurance scheme for tests in the diagnosis of megaloblastic anaemia were reviewed to assess the methods used. Serum folate assays showed great variation between methods, partly due to limitations in assessment by external quality assurance. Red cell folate assays yielded widely different results and much imprecision due both to the differences in preparation of the haemolysate and to the problems inherent in radioassay of a mixture of folate compounds. Intrinsic factor antibody tests showed appreciable variation in sensitivity. There was considerable inconsistence in the detection of polymorph nuclear hypersegmentation.

Regional trials in haematology provide laboratories with external quality assurance. We have organised a scheme for vitamin assays for some years, ${ }^{1}$ adding two other tests more recently. The number of participants, however, permits not only an assessment of individual performance but also of the methods in use. The results of the trial give an indication of current practice.

\section{TRIALS}

Vitamin assays

Two samples are issued 11 times yearly for serum vitamin B12 and folate assays with a whole blood specimen in CPD-adenine for red cell folate assays. An arbitrary haematocrit of 0.45 and serum folate of $1.0 \mu \mathrm{g} / 1$ were given with the whole blood sample. Table 1 shows the methods and the present number of laboratories making returns with them (in parentheses). On average, $90 \%$ of participants report vitamin B12 results, and $86 \%$ folate results. We recorded only those results which reflected the performance of the assay methods in routine practice, omitting those using materials other than serum and whole blood.

The relative accuracy of vitamin B12 methods was compared by taking the microbiological assay results and regarding their mean in each trial as $100 \%$. For serum and red cell folate assays, the results by lactobacillus casei were taken to be $100 \%$. Truncation, depending on the number of returns, ${ }^{2}$ was applied to each method mean. Precision after truncation was determined when there were five or more returns for a method. Participants interpreted their results as low, indeterminate, normal, or high.

A secondary liquid reference serum, standardised against the British standard for human serum vitamin B12, assigned a value of 355 (338-372) $\mathrm{ng} / \mathrm{l}$ by our radioisotopic non-commercial assay, was distributed as an unknown serum in a recent trial.

\section{Intrinsic factor antibody (IFA) tests}

On two occasions pooled pernicious anaemia serum,

Table 1 Methods currently used and No of laboratories making return

\begin{tabular}{lcr}
\hline & Vitamin BI2 & Folate \\
\hline $\begin{array}{lcr}\text { Lactobacillus leichmannii } \\
\text { Euglena gracilis }\end{array}$ & 9 & \\
Lactobacillus casei & 2 & \\
Chloramphenicol-resistant & & 4 \\
$\quad$ Lactobacillus casei & & 12 \\
Radioisotopic non-commercial & 9 & 1 \\
Amersham & 20 & 19 \\
Becton Dickinson & 117 & 117 \\
Biorad & 6 & 7 \\
Micromedic & 14 & 15 \\
Corning & 6 & 4 \\
Diagnostic Products & 3 & 3 \\
\hline
\end{tabular}


control serum, and one or more dilutions of one in the other were issued.

\section{Polymorph neutrophil hypersegmentation}

Stained blood films were sent out on two occasions: on the first, brief details of the patient were givenmild macrocytosis without anaemia and equivocal vitamin assays. On the second, a blood film from the same patient after three months of treatment with folic acid, which reduced the mean cell volume to normal, and a film from a patient with early pernicious anaemia were distributed without any clinical data. A yes or no answer was requested to the question, "is hypersegmentation present?", together with a score if this was the laboratory custom.

\section{Results}

VITAMIN B12 ASSAYS

Accuracy

Fifty issues of normal sera had been made during the period under review. Table 2 shows the annual mean concentrations by each method as a percentage of the microbiological mean. The average of all methods was close to that of the reference methods, and most differences were consistent. The number of users of each method varied considerably, but the overall average was not noticeably affected by weighting each method result by the number within it. The grand mean of the secondary reference preparation from 176 participants was $361 \mathrm{ng} / \mathrm{l}$. The number using the solid phase Becton Dickinson kits permitted separate analysis of their performance in recent trials (table 3 ). With five normal sera the solid phase means were higher than the solid phase no-boil and the liquid Simultrac means. The differences between the liquid and solid phase were significant at the $5 \%$ level with four sera, and between solid phase and solid phase no-boil, with three sera by unpaired $t$ tests. With two pernicious anaemia sera the solid phase and liquid system means were similar and the solid phase no-boil means lower.

Sera spiked with cobinamide $(10 \mu \mathrm{g} / \mathrm{l})$ were issued three times. An excessive increment over the untreated sample result was no more common than may have arisen from imprecision.

\section{Interpretation}

With five pernicious anaemia sera there were 44 "normal" returns from 193 assays. The incidence did not correlate with method, except that it was most common with radioisotopic non-commercial in the earlier years, and for all methods it was inversely related to the mean vitamin $\mathrm{B} 12$ concentration; there were no errors by Euglena. Five of the 44 errors were clerical.

\section{Precision}

There was steady improvement in precision from an average coefficient of variation (CV) for all methods of $20.7 \%$ in 1982 to $15.1 \%$ in 1985 . Table 4 shows the method means from the results of 17 assays of normal sera in 1985.

\section{SER UM FOLA TE ASSA YS}

Relative accuracy

The differences in the annual means of the methods have been fairly consistent over the last four years. Chloramphenicol resistant $L$ casei, except during a period in 1982, was higher, Amersham, Becton Dickinson, and Micromedic were lower, and Biorad, Cor-

Table 2 Relative accuracy of serum vitamin B12 assays

\begin{tabular}{|c|c|c|c|c|c|c|c|c|}
\hline Year & Radioisotopic non-commercial & Amersham & Becton Dickinson & Biorad & Micromedic & Corning & Diagnostic Products & Mean \\
\hline $\begin{array}{l}1982 \\
1983 \\
1984 \\
1985\end{array}$ & $\begin{array}{r}105 \\
98 \\
99 \\
101\end{array}$ & $\begin{array}{l}93 \\
87 \\
86 \\
90\end{array}$ & $\begin{array}{l}98 \\
96 \\
96 \\
93\end{array}$ & $\begin{array}{r}105 \\
95 \\
104 \\
100\end{array}$ & $\begin{array}{l}117 \\
111 \\
107\end{array}$ & $\begin{array}{r}108 \\
102 \\
106 \\
95\end{array}$ & 92 & $\begin{array}{r}102 \\
99 \\
100 \\
97\end{array}$ \\
\hline Mean & 101 & 89 & 96 & 101 & 112 & 103 & 92 & 99 \\
\hline
\end{tabular}

Table 3 Assays with three Becton Dickinson kits

\begin{tabular}{lccc}
\hline & Liquid system & Solid phase & solid phase no-boil \\
\hline Serum vitamin $\mathrm{B}_{12}(\mathrm{ng} / \mathrm{l})$ & & & \\
$\quad 5$ normal & $367(456)$ & $394(84)$ & $373(35)$ \\
2 pernicious anaemia & $88(169)$ & $87(28)$ & $49(12)$ \\
Serum folate $(\mu \mathrm{g} / \mathrm{l})$ & $3 \cdot 5(436)$ & $3.6(90)$ & $4.2(37)$ \\
$\begin{array}{l}\text { Red cell folate }(\mu \mathrm{g} / \mathrm{l}) \\
\% \text { reported subnormal }\end{array}$ & $217(460)$ & $160(59)$ & $198(36)$ \\
\hline
\end{tabular}


ning, and diagnostic products were close to the Lactobacillus case $i$ mean each year. Table 5 shows the results from 1985, together with the results of two recovery experiments.

With Becton Dickinson liquid and solid phase systems the results were close to each other and the solid phase in-boil system higher (table 3 ).

\section{Precision}

The average CV for the kit methods in each trial has decreased by $5 \%$ during the past four years to $18 \%$, whereas that of chloramphenical resistant $L$ case $i$ has worsened by $3 \%$. Table 4 shows the average annual CVs for normal sera during 1985.

\section{RED CELL FOLATE ASSAYS}

\section{Relative accuracy}

Table 5 shows the relative means, as a percentage of lactobacillus casei $(100 \%)$, from assay of normal samples during 1985 . Overall, the annual kit means have decreased from 136 to $114 \%$ in the past three years, with the greatest reduction from 157 to $73 \%$ by Biorad. Amersham and Corning showed little change during this period.

Table 3 shows the results with three samples by Becton Dickinson kits. The differences between the liquid and solid phase were significant with each sample.

\section{Precision}

Table 4 shows the means of the trial CVs during 1985 for methods with eight or more participants.

INTRINSIC FACTOR ANTIBODY (IFA) TESTS

Thirty five laboratories did these tests. Two issues of sera were made with 29 returns from the first and 26 from the second. The first issue was of three sera (one normal), the second a pool of pernicious anaemia sera, and the third a mixture of both to give a low antibody titre. All participants recorded the first negative and the second positive. In the second trial a strongly positive serum and $\times 10, \times 20$, and $\times 40$ dilutions of it in normal serum were issued. Twenty of the 25 tests on the neat and $\times 10$ and $\times 20$ dilutions were found to be positive, and all but one laboratory found the normal serum negative. Table 6 combines the results of the tests on the $\times 40$ dilution and the third serum of the first trial, and these are listed according to method. The incidence of positive results in the home brew group, according to method, were two of 15 (Gottlieb et $\mathrm{al}^{3}$ ), two of six (Ardeman and Chanarin $\left.{ }^{4}\right)$, three of eight $\left(\right.$ Ghazi $\left.^{5}\right)$, and one of one $\left(C n^{6}\right)$. Seven laboratories recorded antibody concentration ranging from 2.0 to 21.3 (median 9.8), 1.0 to $7 \cdot 1$ (median 4.3 ), and 0 to 3.5 (median 2.0 ) units $/ \mathrm{ml}$ with the $\times 10, \times 20$, and $\times 40$ dilutions, respectively, of the positive serum.

POLYMOR PH NEUTROPHIL HYPERSEGMENTATION Sixty three of the 90 replies to the first issue were affirmative. Table 7 shows the 137 replies to slide 2 , from the same patient after folic acid treatment, and to slide 3 , from the patient with pernicious anaemia. The 98 negatives to slide 2 and 100 positives to slide 3 were consistent with the clinical data: $50 \%$ reported both correctly; $23 \%$ showed a positive bias; $21 \%$ a negative bias.

\section{Discussion}

Seven assessments of the currently used kits for vitamin B12 and folate assays have been reported. ${ }^{7-10}$

Table 4 Average trial of CVs \% for precision

\begin{tabular}{|c|c|c|c|c|c|c|}
\hline & $\begin{array}{l}\text { Lactobacillus } \\
\text { casei }\end{array}$ & $\begin{array}{l}\text { Chloramphenical resistant } \\
L \text { casei }\end{array}$ & $\begin{array}{l}\text { Radioisotopic } \\
\text { non-commercial }\end{array}$ & Amersham & Becton Dickinson & Micromedic \\
\hline $\begin{array}{l}\text { Vitamin B12 } \\
\text { Serum folate } \\
\text { Red cell folate }\end{array}$ & $19.9(9)$ & $\begin{array}{l}20 \cdot 7(11) \\
25 \cdot 7(11)\end{array}$ & $18 \cdot 1(8)$ & $\begin{array}{l}12 \cdot 5(19) \\
24 \cdot 4(18) \\
34 \cdot 9(16)\end{array}$ & $\begin{array}{l}14 \cdot 3(103) \\
16 \cdot 7(97) \\
34 \cdot 8(91)\end{array}$ & $\begin{array}{l}10 \cdot 6(13) \\
15 \cdot 0(15) \\
21 \cdot 4(11)\end{array}$ \\
\hline
\end{tabular}

Figures in parentheses represent average number of returns per trial analysed after truncation.

Table 5 Folate assays

\begin{tabular}{|c|c|c|c|c|c|c|}
\hline $\begin{array}{l}\text { Lactobacillus } \\
\text { casei }\end{array}$ & $\begin{array}{l}\text { Chloramphenical resistant } \\
\text { L casei }\end{array}$ & Becton Dickinson & Biorad & Micromedic & Corning & $\begin{array}{l}\text { Diagnostic } \\
\text { products }\end{array}$ \\
\hline \multicolumn{3}{|c|}{ Mean of assays of 13 sera compared with Lactobacillus casei $(100 \%=4.4 \mu \mathrm{g} / \mathrm{l})$} & 98 & 87 & 104 & 96 \\
\hline \multicolumn{2}{|c|}{ Percentage recovery of $5.0 \mu \mathrm{g} / \mathrm{l}$ folic acid added to 2 sera } & 94 & 94 & 70 & 87 & 95 \\
\hline \multicolumn{7}{|c|}{$\begin{array}{l}\text { Means of assays of } 12 \text { whole blood samples compared with Lactobacillus casei }(100 \%=\underset{111}{94}=204 \mu \mathrm{g} / 1) \\
100\end{array}$} \\
\hline
\end{tabular}


Table 6 Results with two sera for intrinsic factor antibody tests

\begin{tabular}{llll}
\hline Method & Positive & Indeterminate & Negative \\
\hline Non-commercial & 8 & 2 & 21 \\
Becton Dickinson & 5 & 1 & 0 \\
$\quad$ kit reagents & 3 & 5 & 2 \\
Corning & 6 & 1 & 1 \\
Diagnostic products & 6 & & \\
\hline
\end{tabular}

Table 7 Neutrophil hypersegmentation: replies to questionnaire

\begin{tabular}{|c|c|c|c|}
\hline \multirow{3}{*}{ Slide 3} & & No & Yes \\
\hline & Yes & 69 & 31 \\
\hline & No & 29 & 8 \\
\hline
\end{tabular}

A full evaluation of even only two or three requires much time, has usually to be limited to only a few different batches, and will show the method under the most ideal conditions. The results from quality assurance schemes can supplement kit assessments, indicating the performance over a period of time in a variety of laboratories.

Radioisotope assays of vitamin B12 assays have improved considerably since our previous review. ${ }^{1}$ The most important change has been in their relative accuracy. The differences between kits has narrowed, and the mean produced by all participants can now be taken as close to the "true" value, as determined by the chosen reference method, when normal sera are assayed. It would be unwise to assume that the convergence of means would also apply at lower levels, though all kits used in the trials in the past four years differentiate pernicious anaemia sera from normal. A comparison of many methods ${ }^{11}$ showed that all were capable of distinguishing normal from abnormal sera, providing that the user's own reference range was considered.

The secondary reference serum preparation, which will be checked periodically against the British primary standard, is now available to all trial participants. We would encourage any laboratory to produce its own normal serum pool, standardised against the secondary perparation.

The assay of serum folate has not shown the same improvement. The differences in relative accuracy have been fairly constant over the past four years (diagnostic product not included before 1985), though precision has improved. The means by Amersham are considerably lower than the others though the manufacturer's reference range is not. We do not now add ascorbic acid to the issued sera because of their simultaneous use for vitamin B12 assays, but when we did before 1985, similar differences were observed.
Not only have the Amersham means been lower but the incidence of interpretations as subnormal have been higher. An average $95 \%$ recovery was obtained from the addition of folic acid to ascorbate treated sera on three occasions. Amersham International PLC recognise the production of low results with quality assurance materials, consider it to be due to oxidation of methylfolate, and offer a modified protocol (addition of dithiothreitol) for testing these. The other kits provide the reducing agent for routine use. Lower folic acid recovery was found with Micromedic and Corning, the two kits with methylfolate standards.

The Lactobacillus casei method was chosen as the assay against which the others were compared, though it contained a decreasing number of participants. Comparison with chloramphenical resistant $L$ case $i$ would have shown even greater differences for most methods. Chloramphenical resistant $L$ casei means have been regularly higher than lactobacillus casei means, except for a period in 1982.

The relative accuracy of red cell folates is most different with Amersham. This kit gave the highest results. The use of sodium ascorbate instead of ascorbic acid distinguishes the haemolysate preparation of this kit from the others. At its $\mathrm{pH}$ both haemolysis and deconjugation will be incomplete, and conditions at the binding stage will favour affinity for polyglutamates if these are still present. The concentration of folate ${ }^{712}$ and the incubation time of the haemolysate ${ }^{712}$ affect the results with some kits. The estimation of red cell folate is of greater clinical value than that of serum folate ${ }^{13}$ and the need for a red cell folate standard is evident.

The Wellcome immunoassay quality control programme issued an advisory note concerning the higher vitamin B12 and serum folate results with the Becton Dickinson solid phase kit. Our results agree with it but show that it may not apply to the solid phase no-boil kit for vitamin B12 and red cell folates. Most manufacturers recommend that kit users should determine their own reference intervals, but differences in interpretation of some results with Becton Dickinson kits suggest that this is not universally done.

The results of IFA tests show that strong antibodies and normal sera are correctly diagnosed by all methods. The tests using commercial reagents are superior to the in-house procedures in the detection of weak antibodies. The method of Gottlieb et al ${ }^{3}$ which does not allow for the effect of serum binding, gave the lowest incidence of positive results. We have not tested specificity.

Most laboratories undertake assessment of polymorph nuclear segmentation. The two trials we carried out show that there is appreciable discrepancy. There is evidently difficulty in deciding what may con- 
stitute discrete lobes or what the reference range is, or both. At a subsequent meeting trial participants were asked to count the lobes of a nucleus shown in a projected transparency. The responses varied from three to eight, with two thirds agreeing on six lobes. Although not a specific finding for vitamin deficiency, hypersegmentation is of high sensitivity in patients with megaloblastic anaemia, ${ }^{14}$ and an increase in segmentation may occur with a fall in the serum vitamin B12 even before the dU suppression test becomes abnormal. ${ }^{15}$ The trials show that if the assessment is to be generally useful more familiarity with normal films and what constitutes an individual lobe seem to be required.

We thank Mr B Orton, Miss D Heap, and Mr P Shackleton for help with the organisation of the trials and the trial participants for their cooperation.

\section{References}

1 Dawson DW, Fish DI, Frew IDO, Orton B, Roome T. Vitamin B12 quality control trials. Clin Lab Haematol 1981;3:323-30.

2 Varley H, Gowenlock AH, Bell M. Practical clinical biochemistry. vol 1. 5th ed. London: Heinemann, 1980:301-2.

3 Gottlieb C, Lau K-S, Wasserman LR, Herbert V. Rapid charcoal assay for intrinsic factor (IF), gastric juice unsaturated B12 binding capacity, antibody to IF, and serum. unsaturated B12 binding capacity. Blood 1965;25:875-85.

4 Ardeman S, Chanarin I. Assay of gastric intrinsic factor in the diagnosis of Addisonian pernicious anaemia. Br J Haematol 1965;11:305-14.

5 Ghazi HA. Effect of serum vitamin B12 binding on intrinsic factor antibody detection in pernicious anaemia. Acta Haematol 1972;47:264-8.

6 Conn DA. Intrinsic factor antibody detection and quantitation. Med Lab Sci 1986;43:48-52.

7 Bain B J, Wickramasinghe SN, Broom GN, Litwinczuk RA, Sims J. Assessment of the value of a competitive protein binding radioassay of folic acid in the detection of folic acid deficiency. J Clin Pathol 1984;37:888-94.

8 Raniolo E, Phillipou G, Paltridge G, Sage R E. Evaluation of a commercial radioassay for the simultaneous estimation of vita$\min$ B 12 and folate, with subsequent derivation of the normal reference range. J Clin Pathol 1984:37:1327-35.

9 Gilois CR, Beattie G, Mills SP. Measurement of vitamin B12 and serum folic acid: a comparison of methods. Med Lab Sci 1986;43:140-4.

10 Sheridan BL, Pearce L. Vitamin B12 assay compared by use of patients' sera with low vitamin B12 content. Clin Chem 1985;31:734-6.

11 International Committee for Standardization in Haematology. Proposed serum standard for human serum vitamin B12 assay. Br J Haematol 1986;64:809-11.

12 Shane B, Tamura T, Stokstad R. Folate assay: A comparison of radioassay and microbiological methods. Clin Chim Acta 1980;100:13-9.

13 Chanarin I. The megaloblastic anaemias. 2nd ed. Oxford: Blackwell Scientific Publications, 1979:194.

14 Lindenbaum J, North BJ. Megaloblastic anaemia and neutrophil hypersegmentation. Br J Haematol 1980;44:511-3.

15 Blundell EL, Matthews JH, Allen SM, Middleton AM, Morris JE, Wickramasinghe SN. Importance of low serum vitamin B12 and red cell folate concentrations in elderly hospital inpatients. $J$ Clin Pathol 1985;38:1179-84.

Requests for reprints to: Dr DW Dawson, Consultant Haematologist, North Manchester General Hospital, Crumpsall, Manchester M8 6RB, England. 